\title{
Assessment of the physicochemical characteristics of rain and runoff water in University of Maiduguri-Nigeria staff quarters
}

\author{
Waziri, $\mathbf{M}^{\mathbf{1}^{*}}$, Akinniyi, J.A ${ }^{2}$. and Ogbodo, $0 . \mathrm{U}^{2}$ \\ ${ }^{1}$ Department of Chemistry, BAI University Damaturu, Nigeria. \\ ${ }^{2}$ Department of Chemistry, University of Maiduguri, Nigeria. \\ Corresponding author: maimunakadai@yahoo.com
}

\begin{abstract}
Rain water and run-off water samples were collected from five locations ( $\mathrm{NH}$ area, R-line 1, Rline 2, $\mathrm{H}$-line, Abuja areas A and B) in University of Maiduguri staff quarters during the peak of the wet season in August 2010. Samples were analysed for the following physicochemical properties; $\mathrm{pH}$, temperature, conductivity, turbidity, total dissolved solids (TDS), $\mathrm{K}, \mathrm{Mg}$ and $\mathrm{Ca}$ using standard techniques. The levels of the parameters were generally higher in the runoff than in rain water, however all values were found to be within the WHO limit for potable water, with turbidity $(7.42 \pm 0.23 \mathrm{NTU}$ for rain water and $8.50 \pm 0.50 \mathrm{NTU}$ for runoff) and conductivity $(109.4 \pm 2.23 \mu \mathrm{s} / \mathrm{cm}$ for runoff) as noticeable exceptions in $\mathrm{H}$-line and $\mathrm{NH}$ areas respectively, indicating some level of pollution. The residents can minimize the impact of runoffs which contain pollutants by planting a rain garden.
\end{abstract}

Keywords: Rain water, runoff water, potable water, rain garden.

\section{INTRODUCTION}

Fresh water is a very valuable resource and getting more valuable daily. Increasing populations and technological growth have put the ecosystem we depend on under stress and the availability of fresh water is at a very high risk (UN, 2002). Consequently people need to utilize every source of water (surface water, groundwater, oasis water, rain water, etc) to meet their demand.

Rain is liquid precipitation that is the condensation of atmospheric water vapour that is pulled down by gravity into drops of water heavy enough to fall and deposited on the earth surface (Met. Appl. 2009 ; Robert, 2002). Surface runoff on the other hand is the water flow which occurs when soil is infiltrated to full capacity and excess water from rain flows over the land. Precipitation can occur via collision with other rain droplets within a cloud while heavy precipitation occur in mountainous areas where upslope flow is maximized within windward sides of the terrain at elevation.

Populations in most parts of the developing world especially in villages and areas where water is a scarce commodity rely on rain water as the primary source of fresh water, providing suitable environment for diverse ecosystems and crop irrigation. However, human activities such as agriculture, urbanization and the rate of increase of land transformation are alarming. Humans are therefore capable of altering and affecting each part of the hydrologic cycle chemically, physically or biologically. Some impacts may be minor and barely perceptible; others have affected human, degraded rivers, lakes, ground water and rain water to enormous degrees (Ayodele and Abubakar, 1998 ; Ojolo et al. 2007).

EPA (1986) estimates that 77 out of the 127 key pollutants have been detected in urban storm runoff. Rain water pollution is a non-point source of pollution. The porous natural landscapes like forests, grasslands and wetlands can trap rainwater and allow it filter into the ground slowly while runoff tend to reach receiving water gradually. However, non porous landscapes like buildings, roads, parking lots etc do not allow slow percolation of runoff into the ground. Therefore, during heavy rainfall, the runoff that is not absorbed into the ground washes pollutants such as grease, bacteria, animal waste, pesticides, salts, heavy metals etc into nearby water ways without any treatment where it can degrade water sheds. As a result, fish and aquatic species are harmed as well as recreational areas become unsafe due to increase in contaminants (Chang et al. 2004; Simmons et al. 2001 ; Dinrifo et al. 2010). 
The physicochemical characteristics measured in this study are those that affect the rainwater body's health which includes; $\mathrm{pH}$, temperature, conductivity, turbidity, total dissolved solids and metals.

The $\mathrm{pH}$ of water determines the solubility, biological availability of chemical constituents such as nutrients and heavy metals. Unpolluted rain water has a $\mathrm{pH}$ of about 5.6 while alkaline dust can raise the $\mathrm{pH}$ to above 7.0. However, during precipitation, rain water dissolves $\mathrm{CO}_{2}$ and $\mathrm{O}_{2}$ while $\mathrm{CO}$ and $\mathrm{SO}_{x}$ emitted by industries also dissolves in rain water leading to fall in $\mathrm{pH}$ to a value of 4 or below resulting in acid rain. Fog, snow, mist and dew also trap and deposit atmospheric contaminants. Furthermore, environmentalist have reported high acid deposition resulting from fallout of dry $\mathrm{SO}_{4}{ }^{2-}, \mathrm{NO}_{3}{ }^{-}$and $\mathrm{Cl}$ particles which are converted to acids when they dissolve in surface water (Saigo and Dunningham, 1997). Though acid rain does not affect human health directly, some particles associated with it have shown adverse health effects (Pope, 2002; Weathers et al. 2006).

During the rainy season, soil, rocks, roads, construction sites, dumps runoffs pick up a lot of dissolved and particulate materials referred as the total dissolved solids (TDS) which determines the conductivity of the water. Rain water has high conductivity than distilled water due to its ability to dissolve airborne dust and gasses while it is in the air. High levels of dissolved solids in drinking water can make the water to have an unpleasant taste or odour.

Turbidity of water refers to how clear the water is and is caused by the presence of particulate matter such as clay, silt, plankton and colloidal particles. Heavy rain falls, strong winds and convection currents can increase the turbidity of water body to a high degree. The major effect of turbidity is aesthetic and high levels of turbidity for a short period of time may not be significant than a lower persistent level. However, high turbidity in drinking water which correlates positively with TDS can cause colour/odour problems (Chaudhary and Inayat, 1990; Chhatawal, 1998).

Temperature is important because the rate of chemical reactions increases at higher temperatures, which in turn affects biological activities and growth of aquatic organisms.

The metals determined in this work include $\mathrm{K}, \mathrm{Ca}$ and $\mathrm{Mg}$ are excellent nutrients in the soil. However, their roles can be affected in cationic exchange process whereby their ions become strongly attached to the negatively charged clay particles in the soil despite the passage of water through the soil. There is also possibility of leaching out of the metal ions from top of the soil into lower subsoil if there is acid deposition whereby hydrogen ions of the acid displaces the metal ions (Batjes, 2002; Nyle, 1990). The objective of this study is to determine the quality of rain and runoff waters within University of Maiduguri staff quarters with a view to highlighting the sources of contaminants and possible effects on the residents.

\section{MATERIALS AND METHODS}

Sampling: Rain and runoff water samples were collected throughout the month of August 2010, from the five locations $(A=N H$ area, $B=R$-line $1, C=R$-line 2, $\mathrm{D}=\mathrm{H}$-line and $\mathrm{E}=\mathrm{Abuja}$ area) within the University of Maiduguri staff quarters.

\section{Analysis}

Determination of physicochemical parameters: Temperature, $\mathrm{pH}$, electric conductivity and total dissolved solids (TDS) were measured immediately on collection of the water samples. $\mathrm{pH}$ was measured using pH meter(Jenway model 350) while conductivity/TDS meter(Hach model 44600) was used to measure the conductivity, temperature and TDS. Turbiditimeter (model Hach 2100 AN) was used to measure the turbidity.

Atomic Absorption spectrophotometer (model analyst 400) was used to determine magnesium and calcium. While potassium was determined using Beckmann flame photometer (Unicam SP 900) at a wavelength of $768 \mathrm{~nm}$.

\section{RESULTS AND DISCUSSION}

The results for the physicochemical parameters analysed for the rain and surface runoff waters are presented in Table 1 and Table 2. 
Am. J. Sci. Ind. Res., 2012, 3(2): 99-102

Table 1: Physicochemical data (mean \pm SME) of rain water in University of Maiduguri Staff Quarters

\begin{tabular}{llllll}
\hline Parameter & \multicolumn{5}{c}{ Location } \\
& \multicolumn{1}{c}{$\mathrm{A}$} & \multicolumn{1}{c}{$\mathrm{B}$} & \multicolumn{1}{c}{$\mathrm{C}$} & \multicolumn{1}{c}{$\mathrm{D}$} & \multicolumn{1}{c}{$\mathrm{E}$} \\
\hline $\mathrm{pH}$ & & & & & \\
Conductivity & $6.90 \pm 0.62$ & $5.82 \pm 0.53$ & $6.15 \pm 0.18$ & $5.97 \pm 0.72$ & $5.74 \pm 0.51$ \\
Temperature & $25.40 \pm 1.56$ & $7.32 \pm 0.38$ & $2.30 \pm 0.20$ & $6.33 \pm 0.30$ & $70.50 \pm 0.95$ \\
Turbidity & $3.00 \pm 0.88$ & $5.30 \pm 0.43$ & $4.52 \pm 0.73$ & $7.42 \pm 0.23$ & $1.71 \pm 0.07$ \\
TDS & $95.32 \pm 3.65$ & $120.33 \pm 1.87$ & $125.20 \pm 2.89$ & $145.15 \pm 4.44$ & $150.45 \pm 0.90$ \\
K & $3.19 \pm 0.40$ & $3.27 \pm 0.19$ & $3.33 \pm 0.18$ & $3.08 \pm 0.16$ & $3.06 \pm 0.12$ \\
Mg & $0.059 \pm 0.48$ & $0.095 \pm 0.03$ & $0.061 \pm 0.02$ & $0.077 \pm 0.015$ & $0.085 \pm 0.03$ \\
Ca & $0.02 \pm 0.05$ & $0.64 \pm 0.15$ & $0.084 \pm 0.02$ & $0.056 \pm 0.008$ & $4.25 \pm 0.20$ \\
\hline
\end{tabular}

Table 2: Physicochemical data (mean \pm SME) of runoff water in University of Maiduguri Staff Quarters

\begin{tabular}{llllll}
\hline Parameter & \multicolumn{5}{c}{ Location } \\
& \multicolumn{1}{c}{$\mathrm{A}$} & \multicolumn{1}{c}{$\mathrm{B}$} & $\mathrm{C}$ & \multicolumn{1}{c}{$\mathrm{D}$} & \multicolumn{1}{c}{$\mathrm{E}$} \\
\hline pH & & & & & \\
Conductivity & $109.4 \pm 2.23$ & $7.65 \pm 0.33$ & $6.71 \pm 0.18$ & $5.90 \pm 0.18$ & $6.24 \pm 0.15$ \\
Temperature & $28.70 \pm 0.57$ & $28.80 \pm 0.60$ & $28.40 \pm 0.30$ & $28.80 \pm 0.54$ & $28.90 \pm 0.50$ \\
Turbidity & $4.50 \pm 0.28$ & $6.22 \pm 0.45$ & $3.50 \pm 0.15$ & $8.50 \pm 0.50$ & $4.63 \pm 0.22$ \\
TDS & $150.32 \pm 1.3$ & $180.33 \pm 1.11$ & $225.20 \pm 2.47$ & $250.15 \pm 1.62$ & $300.00 \pm 8.07$ \\
K & $7.29 \pm 0.13$ & $4.47 \pm 0.19$ & $4.33 \pm 0.27$ & $8.20 \pm 0.15$ & $9.55 \pm 0.36$ \\
Mg & $0.634 \pm 0.12$ & $0.412 \pm 0.08$ & $1.69 \pm 0.06$ & $0.38 \pm 0.03$ & $0.53 \pm 0.03$ \\
Ca & $6.02 \pm 0.07$ & $7.64 \pm 0.35$ & $5.17 \pm 0.22$ & $6.00 \pm 0.15$ & $8.25 \pm 0.16$ \\
\hline
\end{tabular}

The $\mathrm{pH}$ of the rain and run-off waters ranged from $5.90 \pm 0.18$ to $6.71 \pm 0.18$ indicating slight acidity but the $\mathrm{pH}$ of the run- off water which ranged from 5.74 \pm 0.51 to $5.97 \pm 0.72$ indicates some level of acidity. The higher values recorded for the run-off water may be due to pollutants which are washed in to the storm drains. However, all the values fell within the WHO standard of 6.5 to 9.5 (WHO, 2004).

Conductivity estimates the total amount of dissolved ions or the total dissolved salts in the water. High conductivity values were observed for rain water at location $E$ and for the run-off water at all the locations. The high values may be because the rain has accumulated various particles of dust, soil, other household wastes and airborne aerosols that dissolve before deposition. Though the households do not use the rain water for drinking but most of the houses have beautiful landscape and high conductivity can affect the survival of the plants due to high salinity. The total dissolved solids (TDS) values for the runoff were higher than the rain water values but all values were within the safe limits.
The average temperatures of the rain and runoff waters $\left(25.00 \pm 0.23^{\circ} \mathrm{C}\right.$ to $\left.28.90 \pm 0.50^{\circ} \mathrm{C}\right)$ conform with the WHO recommended range of $20-32^{\circ} \mathrm{C}$ and will not constitute any problem to the residents. The turbidity of the rain and runoff waters met the WHO standard of 5NTU for drinking water at all the locations with the exception of locations B and D. High turbidity levels in water are usually associated with disease causing microorganisms. However, the peak of heavy rainfall in the area of study was in the month of August, when water volumes are very high and can stir up and suspend materials resulting in higher turbidity values. Therefore, the high levels of turbidity at some of the locations which is for a short period of time may not be much of a problem than a lower level that persists for a long time.

The concentrations of $\mathrm{K}, \mathrm{Ca}$ and $\mathrm{Mg}$ in the runoff water were higher than the values obtained for rain water. In decreasing order, the following average values were obtained $(\mathrm{K}>\mathrm{Ca}>\mathrm{Mg}$ ) for both runoff water and rain water. The high values in the runoff water may be attributed to water flow over exposed pollutants which is associated with hardness, 
Am. J. Sci. Ind. Res., 2012, 3(2): 99-102

dissolved solids, turbidity and can cause aesthetic problems.

\section{CONCLUSION}

The properties of the rain water investigated met the WHO drinking water standards but most of the values for runoff water exceeded the safe limits. Though the rain water is safe for drinking but presence of dust and other particles is inevitable hence, aesthetically unacceptable however, the water can be used for toilet flush, laundry and irrigation purposes. The residents can also minimize the impact of runoff through a simple environmentally friendly means by planting a rain garden. Rain garden can improve water quality, reduce runoff volumes and generally facilitate infiltration of cleaned water.

\section{REFERENCES}

Ayodele, J.T. and Abubakar, M.B. (1998). Trace element contamination of rain water in the Semiarid region of Kano, Nigeria. J. Environ Mgt and health. 9 (4): 176181

Batjes, A. (2002). Soil Use and Management: Revised Soil parameter estimates for the soil types of the World. Wiley Blackwell. (18) Pp 232-235

Chaudhary, A.A. and Inayat, T. (1990). Ecological Studies at Khairat Lake. Zool. Abstract Series No. 10

Chhatawal, G.R. (1998). Encyclopedia of Environmental Biology. Ammol Pub. Pvt. Ltd. New Delhi, India. Vol 2 pp 237- 301

Chang, M., Matthew, W.M. and Beasley, K. (2004). Roofing as a source of non-point Water Pollution. Jour. Of Environ. Mgmt. 73, 307- 319.

Dinrifo, R.R., Babatunde, S.O.E., Bankole, Y.O. and Demu, Q.A. (2010). Physico-Chemical Properties of Rain Water Collected from Some Industrial Areas of
Lagos State Nigeria. European Journal of Scientific Research Vol.41 (3): 383-390

EPA (Environmental Protection Agency) (1986). Quality Criteria for Water. Document NO. EPA-440/5-86-001 Meteorological Applications (2009). Cambridge Univ. Press. 11(4): 291-300. doi: 10.1017/51350 482704001409.

Nyle, C.B. (1990). The Natural and Properties of Soil. $10^{\text {th }}$ edn. Macmillan: Newyork. Pp 361-339

Ojolo S.J., Oke S.A., Dinrifo R.R. and Eboda F.Y (2007): A survey on the effects of Vehicle emissions on human health in Nigeria. Journal of Rural and Tropical Public Health 6:16-23

Pope, C.A. (2002). Cancer, Cardiopulmonary mortality and long term exposure to fine particulate air pollution. J. Amer. Med. Assoc. 287(9): 1132-1141.

Robert, P.P. (2002). Meteorology at the Millennium. Academic Press. P 66.

Saigo. B.W. and Dunningham, W.P. (1997). Environmental Science. $4^{\text {th }}$ Ed. WCB/Mc Graw-Hill Newyork. Pp 399

Simmons, G., Hope, V., Lewis, G., Whitmore, J. and Gao, W. (2001). Contamination of portable roof-collected rain water in Auckland. Water Res. 35(6): 1518-1524

UN (United Nation) (2003). International Year of rehswater 2003. Retrieved from http://www.un.org/event/water/factsheet.pdf

Weathers, K.C. and Likens, G.E. (2006). Acid rain. In: W.N. Rom (ed). Environmental and occupational Medicine. Lippincott-Raven Pub. Philadelphia.4 $4^{\text {th }}$ edn. Pp 15491561.

World Health Organization (2004). Guidelines for Drinking Water Vol. 1 ( $\left.3^{\text {rd }} \mathrm{Ed}\right)$.

At

http://www.who.int/Water.Sanitation.health/dwq/GDWO 2004web.pdf 